\title{
Population biology of symbiotic amphipods Ischyrocerus spp. and their relationships with the host, the red king crab, in the Barents Sea
}

\author{
A.G. Dvoretsky', T.A. Britayev² \\ ${ }^{I}$ Murmansk Marine Biological Institute KSC RAS, Vladimirskaya Str. 17, 183010 Murmansk, \\ Russia. \\ e-mail:vdvoretskiy@mmbi.info \\ ${ }^{2}$ A.N. Severtsov Institute of Problems of Ecology and Evolution RAS, Leninsky pr. 33, 119071, \\ Moscow, Russia. \\ e-mail: britayev@yandex.ru
}

\begin{abstract}
The relationship between two amphipod species of the genus Ischyrocer$u s$ and the alien species, the red king crab, and the population structure of these amphipods were studied in the Barents Sea. In 2004, 58.4\% and $21.5 \%$ of crabs were colonized by I. commensalis and I. anguipes respectively. For both species of amphipods proportion of crabs with amphipods increased with the increase of the host size. All crabs with carapace width (CW) more than $140 \mathrm{~mm}$ were infested by I. commensalis. For I. anguipes prevalence never exceeded $50 \%$. Small crabs with CW less than 56 $\mathrm{mm}$ were never infested. The amphipods I. commensalis were located on the mouth appendages, gills, pereiopods between basiopodite and ischiopodite as well as between meropodite and carpopodite. Less frequently they were located on the abdomen, carapace, and eggs of crab females. Specimens of I. anguipes were located on the same sites but they were rarely found on the mouth appendages, gills and female eggs masses. The two species co-occurred on 47 crabs out of 132, other crabs were hosts of $I$. commensalis only. In smaller crabs with 60-120 $\mathrm{mm} \mathrm{CW}$, the ratio between amphipod species was 50:50. In larger crabs with $\mathrm{CW}>120 \mathrm{~mm}$, more than $80 \%$ of symbiotic amphipods were I. commensalis. In populations of both species, females were more abundant and larger than males. In both amphipod species, the proportion of females at later stages of maturity increased as crab size increased. There were marked differences in the diameter of the embryo at the first maturity stage and mean individual fecundity between the two amphipod species. These values were $0.40 \pm 0.05 \mathrm{~mm}$ and 23.0 eggs on average in I. commensalis, and $0.28 \pm 0.06 \mathrm{~mm}$ and 7.0 eggs on average in I. anguipes. Our results demonstrated that I. commensalis is more closely associated with the host than I. anguipes. The relationships of both amphipods with the red king crab are discussed.
\end{abstract}

KEY WORDS: red king crab, symbionts, amphipods, population biology, Barents Sea.

Printed in 2010 


\title{
Популяционная биология симбиотических амфипод рода Ischyrocerus и их взаимоотношения с хозяином, камчатским крабом, в Баренцевом море
}

\author{
А.Г. Дворецкий', Т.А. Бритаев²
}

\author{
${ }^{1}$ Мурманский морской биологический институт КНЦ РАН, ул. Владимирская, 17, Мурманск \\ 18310, Россия. \\ e-mail:vdvoretskiy@mmbi.info \\ ${ }^{2}$ Институт проблем экологии и эволючии им. А.Н. Севериова РАН, Ленинский пр. 33, Москва \\ 119071, Россия. \\ e-mail: britayev@yandex.ru
}

РЕЗЮМЕ: Исследованы особенности взаимоотношений двух видов амфипод рода Ischyrocerus c видом-вселенцем камчатским крабом и популяционная структура этих амфипод в Баренцевом море. Показано, что экстенсивность заселения крабов бокоплавами I. commensalis составляла $58,4 \%$, а I. anguipes - 21,5\%. У обоих видов экстенсивность заселения возрастала с увеличением размеров крабов. Все крабы с шириной карапакса (ШК) больше 140 мм были заселены I. commensalis. Для I. anguipes этот показатель не превышал 50\%. На мелких крабах с ШК менее 56 мм симбионты отсутствовали. Обычно амфиподы I. commensalis были локализованы на ротовых придатках крабов, в жабрах, в местах сочленения ходильных конечностей между базиоподитом и ишиоподитом, а также мероподитом и карпоподитом, реже на абдомене, карапаксе и кладке икры самок под абдоменом краба. Локализация особей I. anguipes была сходной, однако эти амфиподы очень редко встречались на ротовых придатках, жабрах и яйцевых кладках крабов. На 47 крабах из 132 оба вида амфипод встречались совместно, на остальных отмечены только особи вида $I$. commensalis. На мелких крабах с ШК 60-120 мм соотношение амфипод составило 50:50. На более крупных крабах более $80 \%$ амфипод составили особи I. commensalis. В поселениях I. commnesalis самок немного больше, чем самцов (54,9\% от численно-

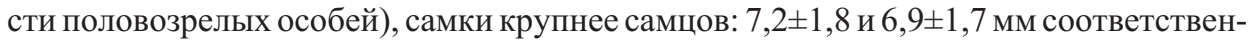
но. В поселениях I. anguipes самок существенно больше, чем самцов $(72,2 \%)$, самки крупнее самцов: $4,2 \pm 1,2$ и $3,6 \pm 0,7$ мм соответственно. У обоих видов с ростом происходит увеличение относительной численности самок на более поздних стадиях зрелости. У I. commensalis диаметр эмбрионов на первой стадии зрелости $0,40 \pm 0,05$ мм, средняя индивидуальная плодовитость составляет 23,0 экз. У I. anguipes диаметр эмбрионов на первой стадии зрелости составляет $0,28 \pm 0,06$ мм, средняя индивидуальная плодовитость 7,0 экз. Показано, что I. commensalis более тесно связан с крабом, чем I. anguipes. Обсуждается характер взаимоотношений амфипод с хозяином.

КЛЮЧЕВЫЕ СЛОВА: камчатский краб, симбионты, амфиподы, популяционная биология, Баренцево море. 


\section{Introduction}

The red king crab, Paralithodes camtschaticus (Tilesius, 1815) has been introduced into the Barents Sea from the Far East seas in the 1960s to improve the economy of the coastal fishery and increase the living standards of the local population (Kuzmin, Gudimova, 2002). At the moment, the species has successfully formed a self-sustaining population at the Murman coast (Kuzmin, 2000; Kuzmin, Gudimova, 2002). Peculiarities of its distribution, reproductive biology and feeding are being actively studied (Bakanev, 2003; Pereladov, 2003; Pavlova, 2007). At the same time, the problem of forming an assemblage of the red king crab symbionts in a new locality remains insufficiently explored. In the North Pacific, such a complex includes various fouling and symbiotic species: hydroids Obelia longissima Pallas, 1776), polychaetes Protoleodora uschakovi Knight-Jones, 1984 (cited as Spirorbis validus in Klitin, 2003) and Pionosyllis magnifica Moore, 1906 (Lopez et al., 2001), fish leeches Crangonobdella fabricii Malm, 1863 and Notostomum cyclostomum Johansson, 1898, barnacles Balanus hesperius Pilsbry, 1916, B. balanoides (L., 1767), and amphipods Ischyrocerus commensalis (Chevreux, 1900) (Klitin, 2003). In the Barents Sea, the symbiont fauna is also diverse and includes fish leeches Johanssonia arctica (Johansson, 1898) and C. fabricii, bivalve mollusks Mytilus edulis (L., 1758) and Anomia squamula (L., 1758), cirriped crustaceans of the family Balanidae, amphipods $I$. commensalis (Kuzmin, 2000) and I. anguipes (Krøyer, 1838) (Dvoretsky et al., 2004).

Crustaceans of the genus Ischyrocerus (order Amphipoda): I. commensalis and I. anguipes are the most common symbionts of the red king crab in the coastal Barents Sea. Both species live in the North Pacific, as well as in the Barents Sea. The amphipod I. commensalis is a widely distributed Boreal-Arctic species mostly occurring at high latitudes and recorded from Newfoundland, Labrador, and southeastern Greenland. It has been reported from the Barents, White, Kara and Chukchi seas, and in the
Bering and Okhotsk seas, at the depths down to 40-100 m (Jashnov, 1948; Gurjanova, 1951; Dunbar, 1954). I. anguipes has a similar distribution, though it is absent from the Kara to Chukchi seas; in the Atlantic its range reaches Denmark and the western Baltic Sea in the south, and in the Pacific it spreads southward to the Japan Sea (Gurjanova, 1951) In summer, it forms aggregations in the water column at the lower border of intertidal zone along open and semi-open areas of the shore (Kuznetsov, 1964).

In the North Pacific, amphipods of the genus Ischyrocerus are known as facultative symbionts of the red king crab (Otto et al., 1990; Shields et al., 1990; Kuris et al., 1991; Klitin, 2003). In the North Atlantic before the increasing of the crab abundance, I. commensalis has been known also as a free-living species (Jashnov, 1948). After the red king crab introduction it has been found in association with the spider crab Hyas araneus (L., 1758) in Norway waters (Johnsen, Vader, 1998). It also infested the snow crab, Chionoecetes opilio (Krøyer, 1838) (Steele et al., 1986), whereas I. anguipes was known only as a freeliving species (Kuznetsov, 1964).

After the establishment of the $P$. camtschaticus population in a new place of habitat, $I$. commensalis has been recorded as its facultative symbiont off the Northern Norway (Johnsen, Wader, 1998) and in the Barents Sea (Kuzmin, Gudimova, 2002). I. anguipes has also recently been recorded as a symbiont of the red king crab in the Barents Sea (Dvoretsky et al., 2004). Both species, especially I. commensalis, can form dense aggregations on $P$. camtschaticus and so may probably affect their host (Klitin, 2003). However, the biology of associated amphipods is virtually unstudied (Dvoretsky et al., 2007). There are no data on their population ecology and reproduction except for free-living I. anguipes (Kuznetsov, 1964). The problem of their relationships with the red king crab is still open. Since both species live in the Barents Sea and in the Far East seas, it is unclear whether the symbiotic populations were introduced together with the crab from the Far East or the local populations passed to symbiotic relations with the crab. 
The aim of the present work was to study the peculiarities of interrelations between symbiotic amphipods of the genus Ischyrocerus and their host - the red king crab, together with investigations of population ecology of both amphipod species. More specifically we studied prevalence and intensity of crab infestation by amphipods, location of the symbionts on the host, and the size- and sex structure of I. commensalis and I. anguipes populations on the red king crab in the Barents Sea.

\section{Material and methods}

The work was based on collections of amphipods living on exoskeleton, gills, mouth appendages and egg masses under abdomen of female of the red king crab. Crabs were sampled during coastal field trips in the Dalnezelenetskaya Bay of the Barents Sea, during July August 2003 and 2004. The number of crabs studied was 38 and 219 specimens respectively. Crabs were collected by scuba diving in depth ranged from 5 to $40 \mathrm{~m}$ and visually examined in the seasonal laboratory of MMBI (Dalniye Zelentsy settlement). All found amphipods were collected and fixed in $4 \%$ formaldehyde. For more accurate collection of small juveniles, they were scraped off from the crab surface with a scalpel. Samples of crab gills with amphipods and their tubes were also fixed.

The following parameters were recorded for each crab: (1) sex, (2) carapace width (CW) and (3) molting stage according to a fourth-level scale: 1 - new shell, carapace soft and clean; 2 - soft shell, carapace clean and firm but retaining elasticity; 3 - old shell, carapace darker than in two former cases, firm, a meropodit breaks at compression; 4 - very old shell, carapace dark, covered with fouling organisms (Manual ..., 1979).

Laboratory processing of amphipods included measurements from the tip of rostrum to the end of telson, weighting with accuracy to 0.001 $\mathrm{g}$, and sex identification. Females were divided into 5 categories (Kjennerud, 1950): 0 - without marsupial plates and eggs, 1 - with growing marsupial plates, 2 - with eggs in a brood pouch, 3 - with juveniles in a brood pouch, 4 with empty brood pouch (juveniles released). The stages of embryo development were defined according a three-stage scale: I - new eggs without segmentation; II — segmented eggs with a well developed eye; III — eggs containing fully formed juveniles.

The relationship between the number of infested hosts and the total number of hosts was defined as "prevalence", whereas "intensity" was the number of symbionts present in each infested host, and "mean intensity" was the mean number of individuals of a particular symbiotic species per infested host in a sample (Martin, Britayev, 1998). In order to study relationships between crab size and indices of infestation, crabs were divided into 4 size classes: 1-50 mm, 51-100 $\mathrm{mm}, 101-150 \mathrm{~mm}$ and $>150 \mathrm{~mm} \mathrm{CW}$. Differences in amphipod prevalences among size classes were examined using contingency tables, while differences in mean intensities were examined using a non-parametric Kruskal-Wallis test. Because no crabs with CW 1-50 mm were infested by amphipods we excluded this size class from the statistical analyzes.

\section{Results}

\section{Host infestation characters}

The minimum size of crabs with symbionts was $56 \mathrm{~mm} \mathrm{CW}$. Number of crabs infested by $I$. commensalis increased as crab size increased (Fig. 1). It was very low in juveniles and sharply increased in mature crabs with $\mathrm{CW}>100 \mathrm{~mm}$ $\left(\mathrm{df}=3, \chi^{2}=168.18, \mathrm{p}<0.001\right)$. This could be connected with both decreased frequency of molting of the given crab size group and with an increase of the total body surface of the hosts. All the crabs with CW > $140 \mathrm{~mm}$ were inhabited with the symbionts. The prevalence of $I$. anguipes also increased with the host size (Fig. 1), being significantly higher in larger crabs $(\mathrm{df}=3$, $\left.\chi^{2}=168.18, \mathrm{p}<0.001\right)$.

Similarly with the prevalence of infestation, mean intensity of I. commensalis increased significantly on the crabs with larger carapaces (Kruskal-Wallis test: $\mathrm{df}=2, \mathrm{H}=19.28, \mathrm{p}<$ 


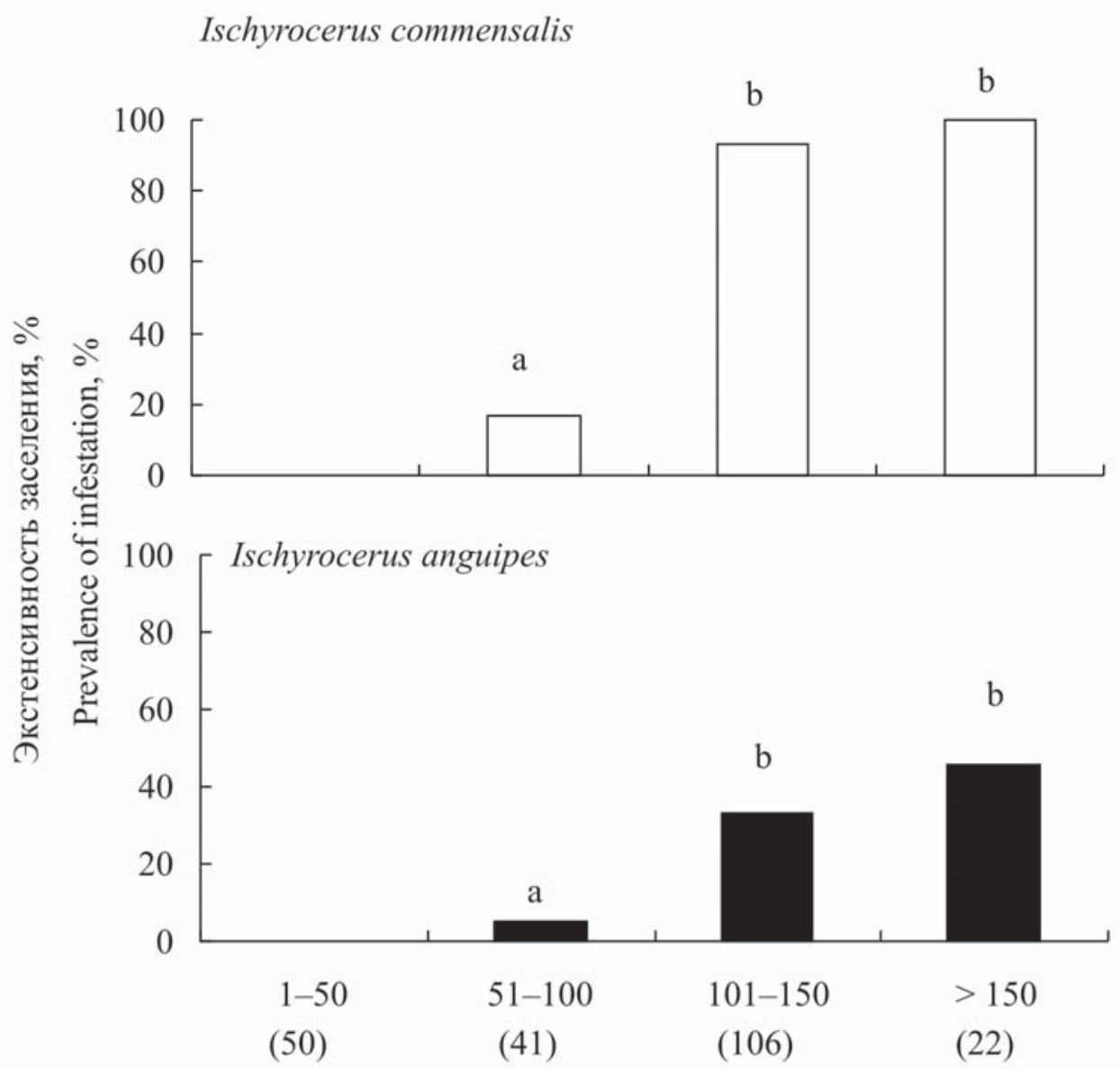

Ширина карапакса, мм

\section{Carapace width, mm}

Fig. 1. Prevalence of Ischyrocerus commensalis and Ischyrocerus anguipes on different-sized red king crabs in Dalnezelenetskaya Bay of the Barents Sea in summer 2004.

Sample size for each size group is indicated in brackets. The same letters indicates no significant difference between size groups $(\mathrm{p}>0.05)$.

Рис. 1. Экстенсивность заселения камчатских крабов разных размерных групп амфиподами Ischyrocerus commensalis и Ischyrocerus anguipes в губе Дальнезеленецкая Баренцева моря летом 2004 г.

В скобках указаны объемы выборок для каждой размерной группы. Одинаковые буквы указывают отсутствие достоверных отличий между размерными классами $(\mathrm{p}>0,05)$.

0.001) (Fig. 2). In contrast, mean intensity of $I$. anguipes was similar in different-sized crabs (Kruskal-Wallis test: $\mathrm{df}=2, \mathrm{H}=1.58, \mathrm{p}=0.452$ ) (Fig. 2).

In our studies, more than $97 \%$ of all crabs were at the second stage of molting. In such crabs the mean intensity of I. commensalis was $50.9 \pm 4.9$ per one crab; in crabs at the third molting stage this index increased to 94.6 \pm 58.1 . For I. anguipes mean intensity was $4.4 \pm 0.9$ and $22.6 \pm 7.6$, respectively. However, it is premature to discuss the dependence of crab infesta- 


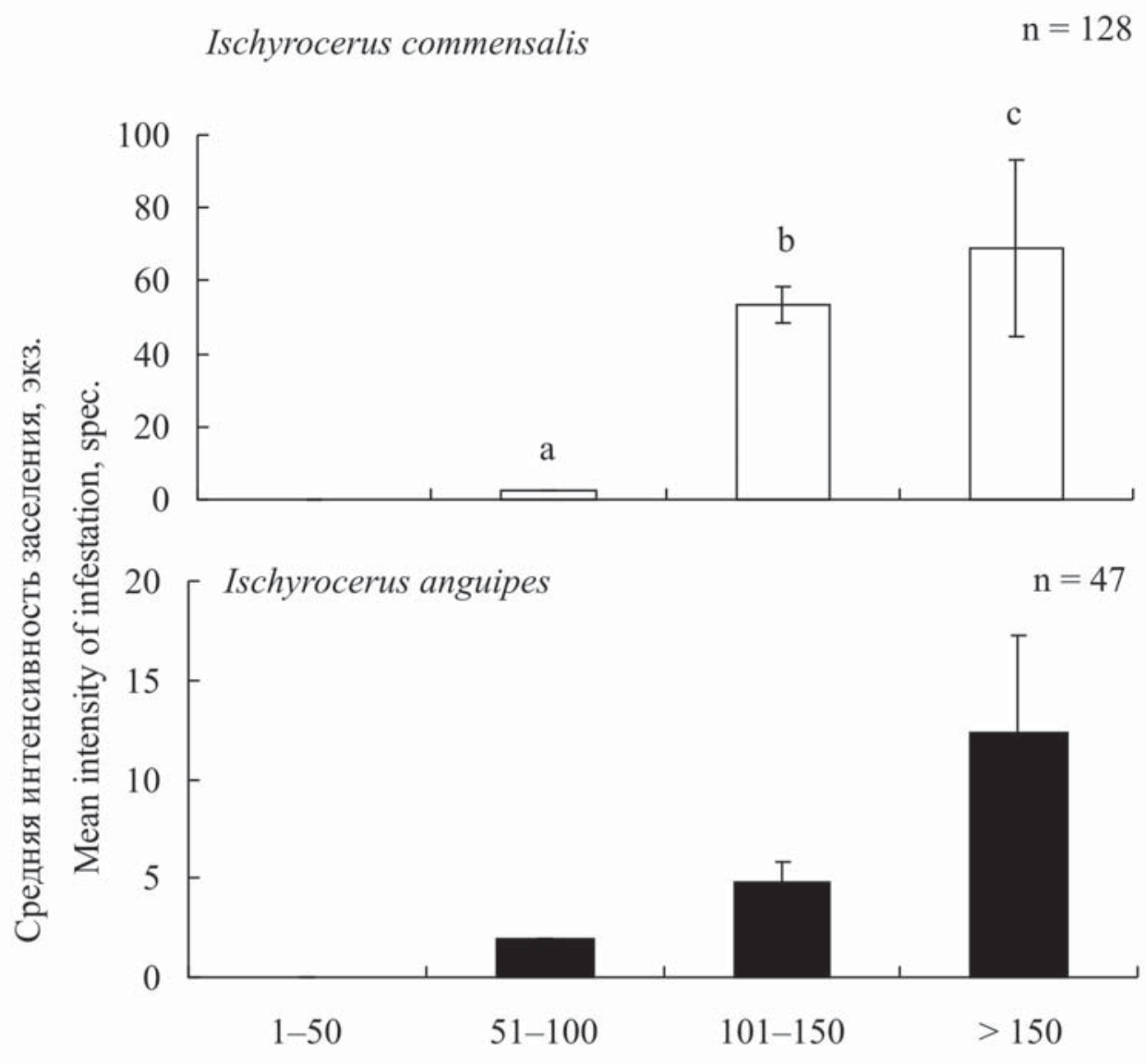

Ширина карапакса, мм

Carapace width, mm

Fig. 2. Mean intensity of Ischyrocerus commensalis and Ischyrocerus anguipes on different-sized red king crabs in Dalnezelenetskaya Bay of the Barents Sea in summer 2004.

Sample size for each size group is indicated in brackets. The same letters indicates no significant difference between size groups $(\mathrm{p}>0.05)$. $\mathrm{n}$ - number of colonized crabs.

Рис. 2. Средняя интенсивность заселения камчатских крабов разных размерных групп амфиподами Ischyrocerus commensalis и Ischyrocerus anguipes в губе Дальнезеленецкая Баренцева моря летом 2004 г.

Одинаковые буквы указывают отсутствие достоверных отличий между размерными классами (p >0,05). $\mathrm{n}-$ количество заселенных крабов.

tion with symbionts on the molting stage of the crabs, because crabs at the first and fourth molting stages were rare in our samples.

We found no relationships between both prevalence and mean intensity of amphipods and depths where the crabs were collected ( $p$ >
0.05 in all cases) (Table 1). On the other hand, the prevalence of I. commensalis was correlated with the size of crabs $\left(r^{2}=0.955, p=0.004\right)$. These findings indicate that variability in infestation indices is connected with variation in crab size rather than depth, that could be explained 
Table 1. Amphipods of the genus Ischyrocerus and the red king crab. Indices of infestation and sizes of crabs collected at different depths in Dalnezelenetskaya Bay, July-August, 2004. N — number of crabs;

CW - carapace width; SE — standard error.

Таблица 1. Амфиподы рода Ischyrocerus и камчатский краб. Индексы заселенности и размеры крабов на исследованном диапазоне глубин в губе Дальнезеленецкая в июле-августе 2004 г. N количество крабов; CW — carapace width; SE — standard error.

\begin{tabular}{|l|c|c|c|c|c|c|}
\hline & & & \multicolumn{2}{|c|}{ Ischyrocerus commensalis } & \multicolumn{2}{|c|}{ Ischyrocerus anguipes } \\
\cline { 4 - 7 } $\begin{array}{c}\text { Depth, } \\
\begin{array}{c}\text { Глубина, } \\
\text { м }\end{array}\end{array}$ & $\mathrm{N}$ & $\mathrm{CW}, \mathrm{mm}$ & $\begin{array}{c}\text { Prevalence, \% } \\
\text { Экстенсивность, } \\
\%\end{array}$ & $\begin{array}{c}\text { Mean intensity } \\
\pm \text { SE, spec. } \\
\text { Средняя } \\
\text { интенсивность, } \\
\text { Эк3. }\end{array}$ & $\begin{array}{c}\text { Prevalence, \% } \\
\text { Экстенсивность, } \\
\%\end{array}$ & $\begin{array}{c}\text { Mean intensity } \\
\pm \text { SE, spec. } \\
\text { Средняя } \\
\text { интенсивность, } \\
\text { Экз. }\end{array}$ \\
\hline $5-12$ & 32 & $71.3 \pm 8.1$ & 34.4 & $21.5 \pm 4.8$ & 15.6 & $2.4 \pm 0.7$ \\
\hline $13-20$ & 68 & $111.7 \pm 5.3$ & 63.2 & $74.1 \pm 8.9$ & 14.7 & $7.2 \pm 2.6$ \\
\hline $21-28$ & 48 & $101.2 \pm 5.9$ & 62.5 & $32.7 \pm 6.3$ & 29.2 & $3.4 \pm 1.0$ \\
\hline $29-36$ & 37 & $119.6 \pm 7.9$ & 75.7 & $39.5 \pm 6.4$ & 32.4 & $4.8 \pm 1.7$ \\
\hline$>36$ & 34 & $91.2 \pm 11.2$ & 47.1 & $80.3 \pm 32.9$ & 17.6 & $17.7 \pm 7.6$ \\
\hline
\end{tabular}

both by wide bathymetric distribution of I. commensalis and migrations of crabs within the studied depth range.

\section{Location}

In large crabs, mass aggregations of symbionts were found near mouth appendages. The majority of adult individuals were recorded at this site. Symbionts were often found on dorsal surface of pereiopods in places of articulation between basiopodite and ischiopodite as well as between meropodite and carpopodite, i.e. in places of accumulation of sand particles allowing amphipods to attach themselves to the crab body. Less frequently the symbionts were recorded on abdomen, carapace, and on eggs laid under abdomen of crab females. In some crabs, amphipods were found on "scars" or mechanically damaged places of exoskeleton.

A number of I. commensalis were recorded in crab gills where they build specific tubes (Fig. $3)$. In the gills they can form dense aggregations. For example, in a male with $200 \mathrm{~mm} \mathrm{CW}$, gills contained 219 amphipods with body length up to $11 \mathrm{~mm}$. Out of 132 crabs with symbionts, 68 (51.5\%) had amphipods I. commensalis in gills, and another 28 had empty tubes. Amphipods occur in gills of crabs with $\mathrm{CW}$ no less than
$120.7 \mathrm{~mm}$. The mean CW of crabs with amphipods in the gills was $144.6 \pm 1.6 \mathrm{~mm}$ (120.7$200.0 \mathrm{~mm}$ ), whereas CW of crabs without amphipods in gills was only $76.0 \pm 4.0(9.1-173.0)$ $\mathrm{mm}$. Statistical analysis indicated a significant difference between these levels (Kruskal-Wallis test: $\mathrm{df}=1, \mathrm{H}=93.32$, $\mathrm{p}<0.001)$. Gills are mostly inhabited by juveniles comprising $80 \%$ of the total number of amphipods. Therefore, the mean length of individuals found in gills was

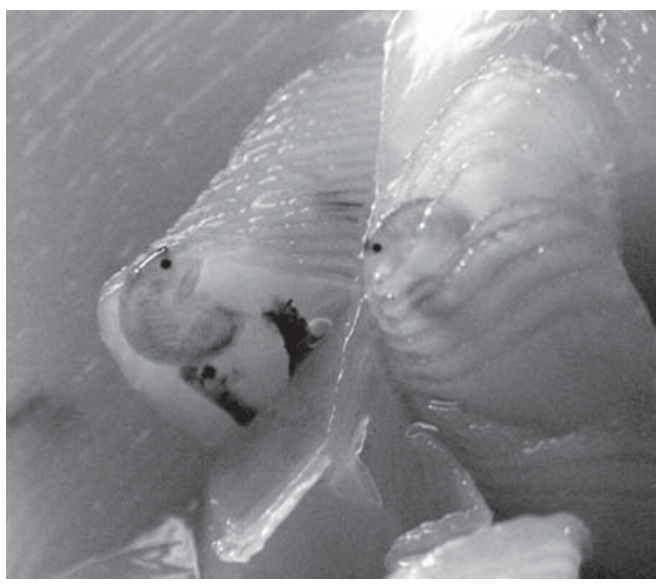

Fig. 3. A fragment of the red king crab gill tissue with tubes of Ischyrocerus commensalism.

Рис. 3. Фрагмент жаберной ткани камчатского краба с домиками Ischyrocerus commensalism. 
Table 2. Morphometric parameters of amphipods Ischyrocerus commensalis and I. anguipes collected from red king crabs in Dalnezelenetskaya Bay, summer 2003-2004.

Таблица 2. Морфометрические показатели амфипод Ischyrocerus commensalis и I. anguipes, собранных с камчатских крабов в губе Дальнезеленецкая в летний период 2003-2004 гг.

\begin{tabular}{|l|c|c|}
\hline \multicolumn{1}{|c|}{$\begin{array}{c}\text { Sex } \\
\text { Пол }\end{array}$} & $\begin{array}{c}\text { Mean body length (min-max) } \pm \mathrm{SD} \\
\text { Длина тела средняя (мин.-макс.) } \\
\text { стандартное отклонение }\end{array}$ & $\begin{array}{c}\text { Mean weight (min-max) } \pm \text { SD Средняя } \\
\text { масса тела (мин.-макс.) } \pm \text { стандартное } \\
\text { отклонение }\end{array}$ \\
\hline \multicolumn{2}{|c|}{ Ischyrocerus commensalis } \\
\hline $\begin{array}{l}\text { Females } \\
\text { Самки }\end{array}$ & $7.2(4.0-12.1) \pm 1.81$ & $8.2(1.0-44.0) \pm 6.11$ \\
\hline $\begin{array}{l}\text { Males } \\
\text { Самцы }\end{array}$ & $6.9(4.1-12.0) \pm 1.70$ & $6.8(0.5-26.0) \pm 5.07$ \\
\hline $\begin{array}{l}\text { Juveniles } \\
\text { Молодь }\end{array}$ & $2.4(0.7-5.0) \pm 1.04$ & $0.6(0.2-2.0) \pm 0.26$ \\
\hline \multicolumn{2}{|c|}{ Ischyrocerus anguipes } \\
\hline $\begin{array}{l}\text { Females } \\
\text { Самки }\end{array}$ & $4.2(2.3-8.0) \pm 1.21$ & $1.7(0.5-12.0) \pm 1.77$ \\
\hline $\begin{array}{l}\text { Малеs } \\
\text { Самцы }\end{array}$ & $3.6(2.3-6.0) \pm 0.71$ & $1.1(0.5-2.5) \pm 0.55$ \\
\hline $\begin{array}{l}\text { Juveniles } \\
\text { Молодь }\end{array}$ & $2.2(1.0-3.8) \pm 0.52$ & $0.5(0.3-1.0) \pm 0.15$ \\
\hline
\end{tabular}

only $3.5 \mathrm{~mm}$. The mean size of males, females, and juveniles of amphipods in gills was less than in the whole population. Large adult amphipods were only recorded in gills of crabs with $\mathrm{CW}>$ $170 \mathrm{~mm}$ that correspondingly have larger gill filaments.

Co-occurrence of amphipods on the red king crab

Analysis of the data obtained in summer 2003-2004 has shown that both amphipod species co-occurred on 47 crabs out of 132, other crabs were hosts of I. commensalis only. The mean CW of the crabs with both amphipod species was $140.4 \mathrm{~mm}(66.3-200 \mathrm{~mm})$. In smaller crabs with CW $60-120 \mathrm{~mm}(\mathrm{n}=3)$ the ratio between amphipods was 50:50. In larger crabs with $\mathrm{CW}>120 \mathrm{~mm}(\mathrm{n}=44)$, more than $80 \%$ of symbiotic amphipods were individuals of I. commensalis. Animals of both species do not form separate aggregations on the crab body except for crab gills where only I. commensalis were found.

Size and sex structure of amphipod populations and sexual dimorphism

A total of 5241 specimens of symbiotic amphipods of the genus Ischyrocerus were analyzed. Vast majority (5019 specimens) belonged to Ischyrocerus commensalis. The population of this species mostly consisted of juveniles. The number of juveniles was more than two times higher than that of adults (3499 and 1520 specimens, respectively) and they comprised $77 \%$ of all individuals in the population. Among adult amphipods, females were slightly more abundant than males: their percentage was $54.9 \%$ (835 females and 685 males). The mean body length was $3.9(3.6-12.2) \mathrm{mm}$, and the mean body weight was 2.3 (1-44) mg. Mean 


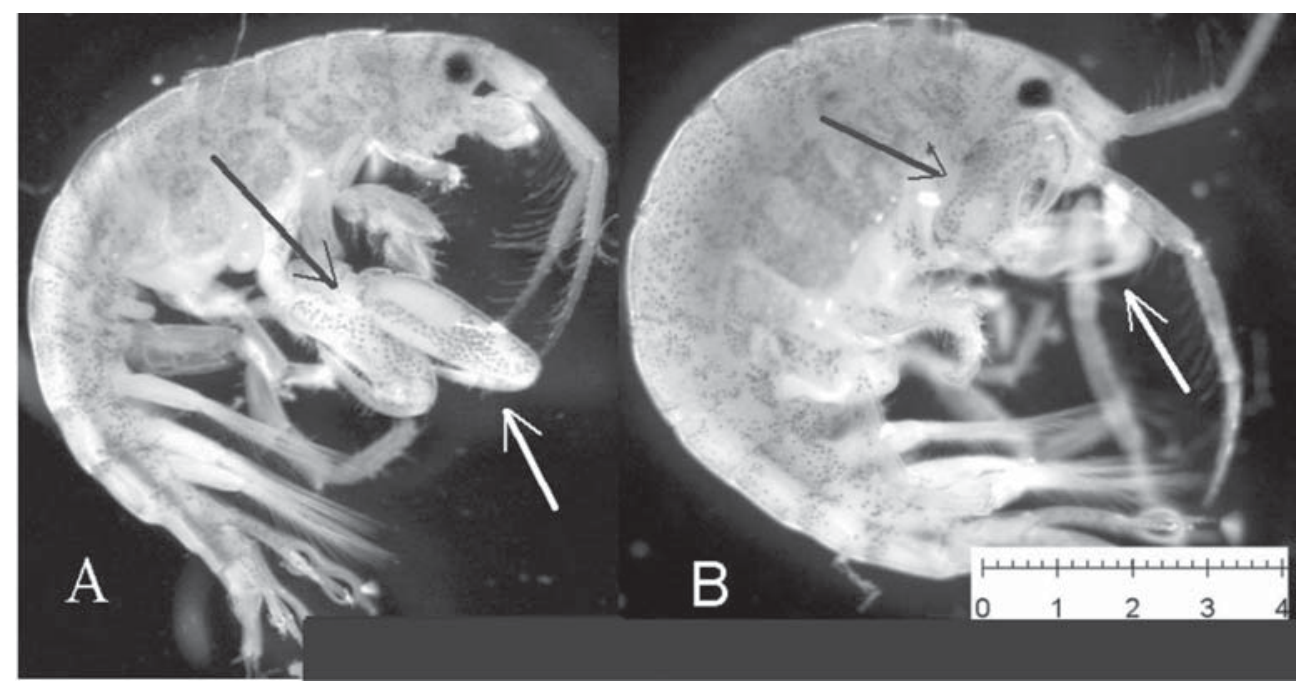

Fig. 4. Male (A) and female (B) of Ischyrocerus commensalis. Arrows indicate second gnathopods, scale bar$4 \mathrm{~mm}$.

Рис. 4. Самец (А) и самка (В) Ischyrocerus commensalis. Стрелками показаны вторые гнатоподы. Масштаб 4 мм.

body length of females was larger than that of males (Kruskal-Wallis test: $\mathrm{df}=1, \mathrm{H}=7.35, \mathrm{p}=$ 0.007) (Table 2).

Among adults, sexual dimorphism expressed itself not only in size but also in the structure of second gnathopods: they are larger in males and the inner margin of the claw bears pinnate setae. Second gnathopods in females are characteristically ascidiform, the inner margin of the claw has no pinnate setae (Fig. 4).

Relation between weight and length of amphipods can be described by an exponential equation, namely: $\mathrm{W}=0.0114 \mathrm{~L}^{3.1948}$ for males, and $\mathrm{W}=0.0101 \mathrm{~L}^{3.2797}$ for females, where $\mathrm{W}$ is weight in $\mathrm{mg}$ and $\mathrm{L}$ is body length in $\mathrm{mm}$. The form of equation for males and females differs insignificantly (Fig. 5).

In total, 222 specimens of I. anguipes collected from the red king crabs were analyzed. Females prevailed in abundance - $60.8 \%$ of the total number of population. The number of juveniles was much lower $-15.8 \%$. The sex ratio was biased toward to females accounting $72.2 \%$ of mature amphipods (135 females and 52 males). This species is smaller than I. commensalis. The mean body length was 2.9 (1.0-
8.0) $\mathrm{mm}$, the mean weight was $0.8(0.3-12.0)$ $\mathrm{mg}$. The data on size and weight in males, females, and juveniles are given in Table 2. Females were larger than males (Kruskal-Wallis test: $\mathrm{df}=1, \mathrm{H}=5.29, \mathrm{p}=0.021)$. Similarly with I. commensalis, the form and structure of second gnathopods differ between adult male and female specimens.

\section{Peculiarities of reproduction}

Material collected from the red king crab allows us to describe the reproductive biology of both species. The data are more detailed for I. commensalis.

An analysis of relationship between body length and maturity stages of females has shown that the relative number of females at later stages of maturity increases as their size increased (Fig. 6A).

Females at stage 0 (without marsupial plates) occur within a narrow size range from 4.0 to 6.3 $\mathrm{mm}$ and comprise $100 \%$ among the smallest individuals $(4.0-4.8 \mathrm{~mm})$. Females at stage 1 (marsupial plates without embryos) occurred in the size range $4.8-7.9 \mathrm{~mm}$ and numerically 


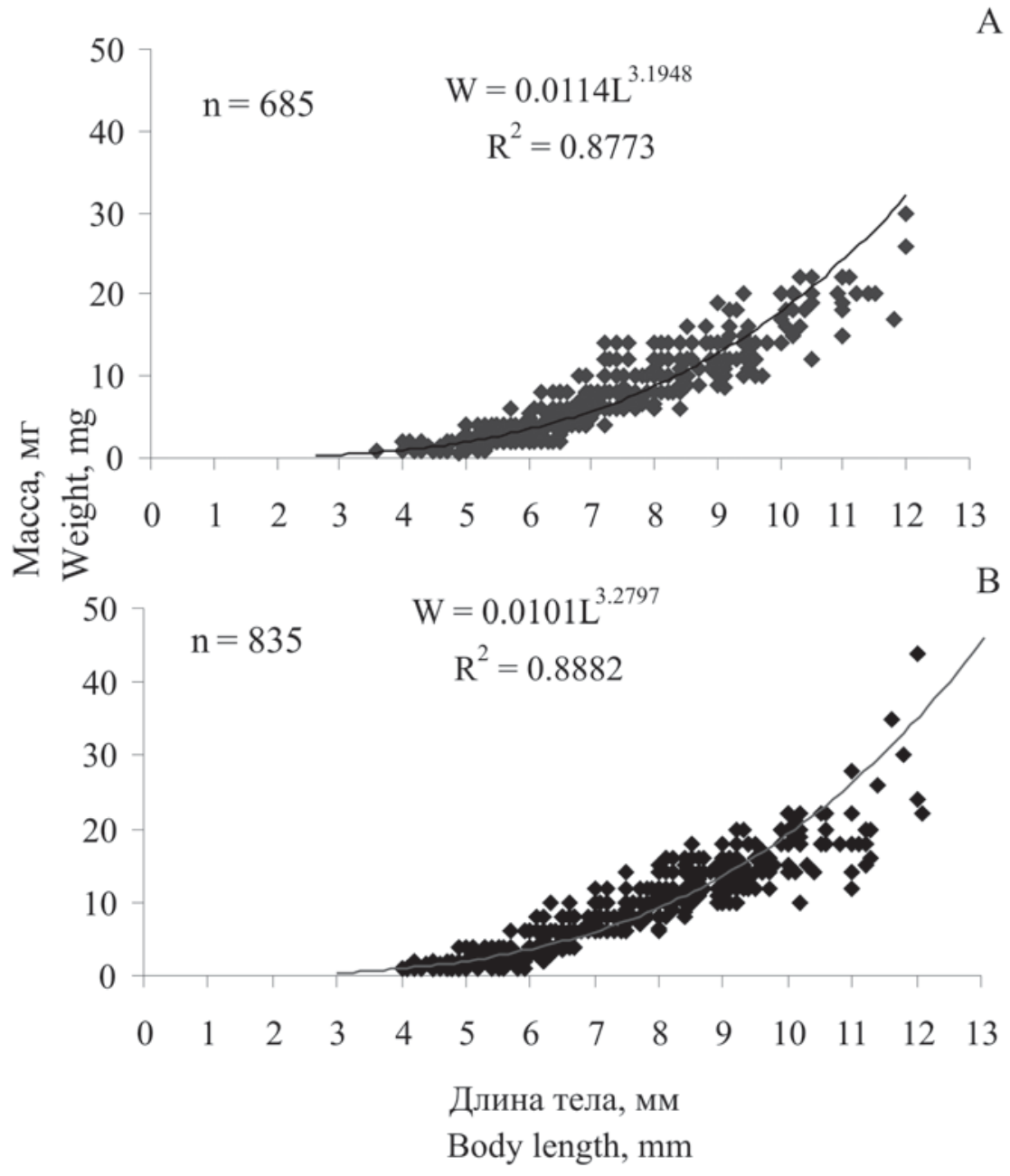

Fig. 5. Relationship of wet weight to body length for male (A) and female (B) of Ischyrocerus commensalis. Рис. 5. Размерно-массовая зависимость для самцов (А) и самок (В) Ischyrocerus commensalis.

dominated among amphipods with 4.8-7.1 mm body length. Females at stage 2 (with embryos in marsupium) prevailed both in size range from 7.2 to $11.1 \mathrm{~mm}$ and in the whole population. The portion of females at stages 3 and 4 (with embryos and having already released juveniles) increases with body size. The size of females at these stages varies from 7 to $12 \mathrm{~mm}$. Their number was low, and they prevailed only among amphipods with body length $>11.2 \mathrm{~mm}$.

The number of eggs in female marsupial pouch (individual fecundity) was 23.0 on aver- age. The mean individual fecundity was higher in larger females (Fig. 7).

The embryo diameter varies from 0.3 to 0.6 $\mathrm{mm}$. It increases as the embryos develop, being $0.40 \pm 0.055 \mathrm{~mm}$ at the first maturity stage, $0.47 \pm 0.083 \mathrm{~mm}$ - at the second stage, and $0.50 \pm 0.016$ - at the third stage. The length of fully formed juveniles were 0.7 to $1.2 \mathrm{~mm}$.

Reproductive characteristics of I. anguipes are similar to those in I. commensalis (Fig. 6 B). Females with eggs (maturity stage 2) also prevailed in the population. An increase in the 

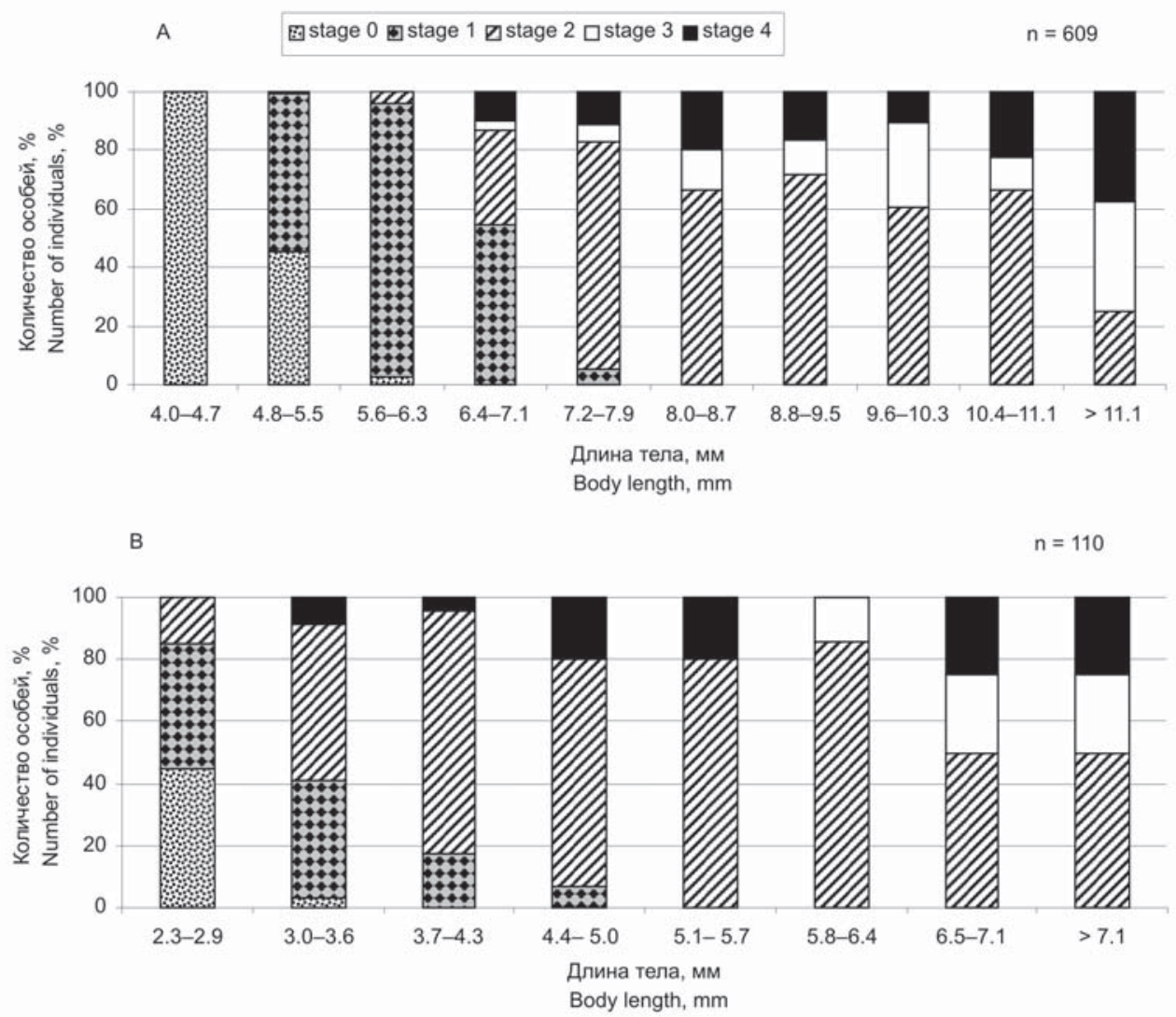

Fig. 6. Size-frequency distributions of Ischyrocerus commensalis (A) and Ischyrocerus anguipes (B) females with different developmental stages in Dalnezelenetskaya Bay, summer July- August, 2003-2004. Рис. 6. Размерный состав самок Ischyrocerus commensalis (А) и Ischyrocerus anguipes (B) разных стадий зрелости в губе Дальнезеленецкая в июле-августе 2003-2004 г.

portion of females at later maturity stages (stage 2 and older) also connected with their growth. However, in I. anguipes, females at stages 1 and 2 are found even among the smallest individuals. This indicates that maturation of the summer generation of $I$. anguipes is more rapid than in I. commensalis.

Mean individual fecundity of females (7.0 embryos) is considerably lower than in I. commensalis, and the embryos are smaller. The diameter of embryos increases with their development: it is $0.28 \pm 0.064 \mathrm{~mm}$ at the first maturity stage, $0.31 \pm 0.062 \mathrm{~mm}$ at the second stage, and $0.34 \pm 0.022 \mathrm{~mm}$ at the third.

Our data suggest that intensive reproductive processes in I. commensalis and I. anguipes occur of in July-August when the final maturation of females and their eggs and a release of juveniles were observed in both amphipod species.

\section{Discussion}

It is known that symbionts can control the population density of crustacean hosts by decreasing their fecundity (Kuris, 1993; Williams, McDermott, 2004). For example, during sharp increases in abundance of symbiotic nemerteans Carcinonemertes epialti Coe, 1902, mortality of embryos of their hosts, the crabs $P$. camtschaticus and Hemigrapsus oregonensis (Dana, 1851), can reach 40-100\% (Wickham et 


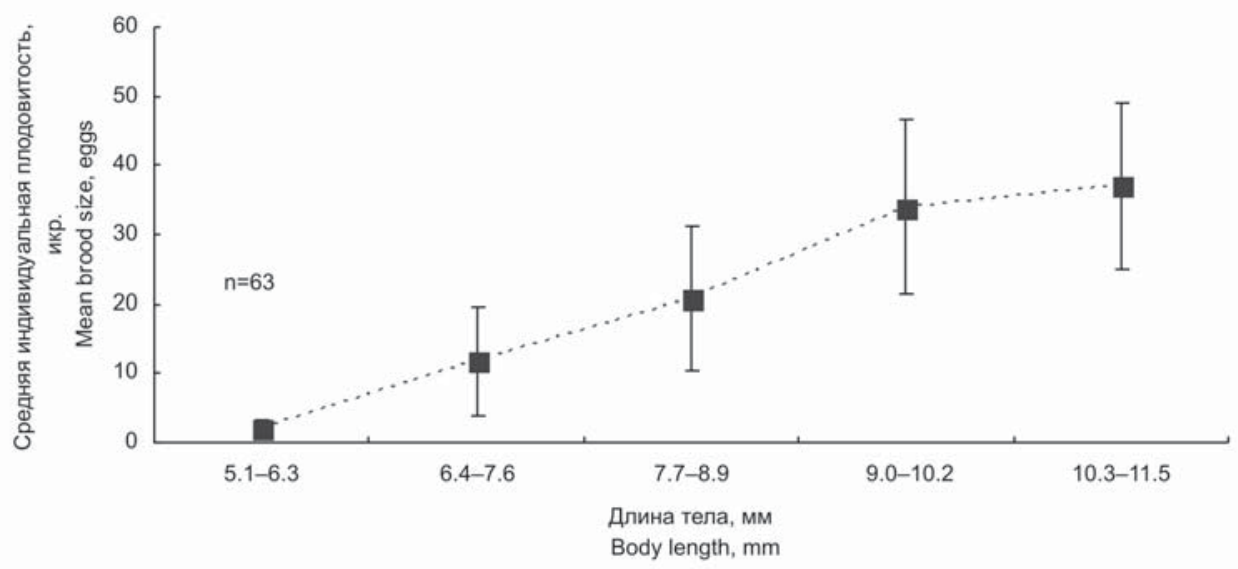

Fig. 7. The relationship between mean brood size and female body length of Ischyrocerus commensalis in Dalnezelenetskaya Bay, July-August 2003-2004. Vertical bars show standard deviation.

Рис. 7. Зависимость средней индивидуальной плодовитости Ischyrocerus commensalis от длины тела самок в губе Дальнезеленецкая июле-августе 2003-2004 г. Вертикальные линии показывают стандартное отклонение.

al., 1985, Shield, Kuris, 1988). According to data of several authors (Otto et al., 1990, Shields et al., 1990; Kuris et al., 1991), species of the genus Ischyrocerus can feed on embryos from egg clutches of the red king crab in Alaskan waters. A similar conclusion was drawn by Klitin (2003), who found I. commensalis near Sakhalin only in egg clutches of female red king crabs. Both species of Ischyrocerus, especially I. commensalis, rapidly colonize red king crabs in the Barents Sea as well. Therefore, it cannot be excluded that in the new habitat they also can feed on crab embryos and negatively affect the crab fecundity. However, special experimental studies are required to confirm this hypothesis.

It should be specially noted that amphipods I. commensalis are abundant in crab gills where they build tubes attached to gill filaments. The size of gill filaments of juvenile crabs and their frequent molting do not allow amphipods to build tubes. This is just the reason why small juvenile amphipods prevail in gills of juvenile crabs. As the crab size increases, the number of amphipods on crab gills also increases, and on large crabs they can form dense aggregations, up to 219 specimens per host. Such a large amount of foreign matter, both amphipods and their empty tubes, in the crab gills could lead to two negative consequences for the host. Firstly, it may impair host respiration as has been shown for other crustacean symbionts (Gannon, Wheatly, 1992; Astall et al., 1996). Secondly, this can lead to the increasing of energetic costs due to the increasing activity of the 5th pair of rudimentary walking legs for cleaning the gills of debris and amphipods.

On the other hand, we observed large amphipod aggregations on limb "scars" and in the places of mechanically damaged carapace. The amphipods colonizing these sites may feed on dead tissues, pathogenic bacteria and fungi. If it is the case, such a relationship should be considered as a cleaning symbiosis. Therefore, it is still difficult to estimate the balance of symbionts-host relationships in this association. Evidently, there is a complex of interactions, quite different from simple commensalism. It may be hypothesized that in a period of very high abundance of amphipods they can negatively affect the reproductive potential of the crab population and affect respiration rates in single crabs. Therefore, a survey of peculiarities of the crab colonization with associated organisms should be included in a routine biological analysis of the crab population. 
Indices of infestation of amphipods on crabs increase with size (age) of the crabs. This can be connected with both increased surface of the crabs (increased area available for colonization) and decreased frequency of crab molting. A similar tendency was also found in the red king crabs off the Western Sakhalin (Klitin, 2003).

I. commensalis is probably more closely associated with the red king crab than $I$. anguipes. High prevalence, intensity of infestation, abundance of juveniles, and the presence of all maturity stages of I. commensalis females on the crabs prove close relationship between this symbiont and its host. Additionally, it was never found in free living state in the area studied. Location of amphipods also proves this hypothesis: I. commensalis were found more frequently on the host gills and mouthparts than I. anguipes. In contrast, I. anguipes had lower prevalence, intensity and number of juveniles on the crab than that of I. commensalis. Moreover, the proportion of I. anguipes females without marsupial plates and eggs (maturity stage 0 ) was very low even among the smallest females, suggests the recruitment of these amphipods from other substrates.

Some significant differences can be mentioned also in life cycle strategies of these species. I. commensalis has larger size, reaches maturity later, and produces more and larger eggs than I. anguipes. Even though we have no data on seasonal dynamics of reproductive processes in I. commensalis and I. anguipes in the Barents Sea, our results show active reproduction of these species on crabs in August, which correspond with data on reproductive activity of free-living populations of the same species both in the North America (Dunbar, 1954) and (for $I$. anguipes) in the Barents Sea (Kuznetsov, 1964). Co-occurrence of amphipods on the red king crabs may be an evidence of either weak interspecific competition between these species, or an absence of such competition.

In conclusion, the role of the red king crab in expansion of the range of amphipods of the genus Ischyrocerus in the Barents Sea should be mentioned. This expansion can lead to a change in abundance of some parasitic species that use amphipods as intermediate hosts. For example, it is known that metacercariae of trematodes Podocotyle atomon (Rudolphi, 1902), whose final hosts are marine fishes, actively infected different small crustaceans, including I. anguipes (Uspenskaya, 1963).

\section{Acknowledgements}

We are grateful to all our colleagues participated in the expeditions to the Barents Sea with special thanks to Dr. S.A. Kuzmin for help in symbionts sampling and useful discussions, divers O.V. Savinkin and Y.A. Zuev for their help with collecting of crabs. We are also grateful to Dr. A.V. Sysoev for the English translation of the manuscript and Dr. A.A. Udalov and Dr. W. Vader for valuable comments they made to improve the quality of our paper. This study was supported by the program of Russian Academy of Sciences «Fundamental basis of biological resources management» and Russian Foundation for Basic Research (project no. 09-0500736-à).

\section{References}

Astall C.M., Taylor A.C., Atkinson R.J.A. 1996. Notes on some branchial isopods parasitic on Upogebiid mudshrimps (Decapoda: Thalassinidea) // Journal of the Marine Biological Association of the UK. Vol.76. P. 821-824.

Bakanev S.V. 2003. [Fecundity and some other reproductive characteristics of the red king crab in the Barents Sea] // Red king crab in the Barents Sea. PINRO Publishing. Murmansk. P.78-87 [in Russian].

Dunbar M.J. 1954. The amphipod Crustacea of Ungava bay, Canadian eastern Arctic. // Journal of the fisheries research board of Canada. Vol.11. P.709-798.

Dvoretsky A.G., Kuzmin S.A., Lyubina O.S. 2004. [Formation of interspecific relations between the red king crab and its commensals in the Barents Sea] // Evolution of marine and terrestrial ecosystems in pereglacial zones. Abstracts of communications at international scientific conference (Rostov-on-Don, September 6-8, 2004). Rostov-on-Don. P.32-36 [in Russian].

Dvoretsky A.G., Kuz'min S.A., Matishov G.G. 2007. [The biology of the amphipod Ischyrocerus commensalis and its symbiotic relationships with the red king crab in the Barents Sea] // Doklady biological sciences. Vol.417. P.453-455 [in Russian]. 
Gannon A.T., Wheatly M.G. 1992. Physiological effects of an ectocommensal gill barnacle, Octolasmis muelleri, on gas exchange in the blue crab Callinectes sapidus // Journal of crustacean biology. Vol.12. P.1118.

Gurjanova V.F. 1951. [Amphipods of the seas of the USSR and adjacent waters (Amphipoda-Gammaridea)]. Moscow-Leningrad: AN SSSR Publishing. 1031 p. [in Russian]

Jashnov V.A. 1948. [Order Amphipoda] // Gaevskaya N.S. (ed.). Guide to the fauna and flora of the northern seas of the USSR. Moscow: Sov. Nauka. P.253-325 [in Russian].

Johnsen J.R., Vader W. 1998. Ishyrocerus commensalis from Paralithodes camtschatica in Northern Norway, a new amphipod for European water // Proceedings and abstracts of the 4th International crustacean congress, Amsterdam, 20-24 July 1998. P.136.

Kjennerud J.I. 1950. Ecological observations on Idotea neglecta G.O. Sars // University i Bergen Aarbok. Vol.7. P.1-47.

Klitin A.K. 2003. [The red king crab along the shores of Sakhalin and the Kuril Islands: biology, distribution, and functional structure of the area]. Moscow. 253 p. [in Russian]

Kuris A.M. 1993. Life cycles of nemerteans that are symbiotic egg predators of Decapod Crustacea: adaptations to host life histories // Hidrobiologia. Vol.266. P.1-14.

Kuris A.M., Blau S.F., Paul A.J., Shields J.D., Wickham D.E. 1991. Infestation by brood symbionts and their impact on egg mortality of the red king crab, (Paralithodes camtschatica) in Alaska // Canadian journal of fisheries and aquatic sciences. Vol.48. P.559-568.

Kuzmin S.A. 2000. [Biology, distribution and abundance dynamics of the red king crab, Paralithodes camtschaticus (Tilesius, 1815) in the Barents Sea]. Autoreferate of Candidate [Ph.D.] of Biological Sciences Thesis. Moscow. 24 p. [in Russian]

Kuzmin S.A., Gudimova E.N. 2002. [Introduction of the Kamchatka (red king) crab in the Barents Sea. Pecularities of Biology, Perspectives of Fishery]. Apatity: Kolskiy Nauchny Tsentr RAN. 236 p. [in Russian]

Kuznetsov V.V. 1964. [The biology of abundant and the most common species of crustaceans in the Barents and White seas]. Moscow: Nauka. 244 p. [in Russian]

Lopez E., Britayev T.A., Martin D., San Martin G. 2001. New symbiotic associations involving Syllidae (Annelida: Polychaeta), with taxonomic and biological remarks on Pionosyllis magnifica and Syllis cf. armillaris. // Journal of the Marine Biological Association of the UK. Vol.81. P.399-409.

[Manual on studying the decapod crustaceans Decapoda of Far East seas]. 1979 / Compiled by V.E. Rodin, A.G. Slizkin, V.I. Myasoedov, V.N. Barsukov, V.V. Miroshnikov, K.A. Zgurovsky, O.A. Kanarskaya, V.Ya. Fedoseev. Vladivostok: TINRO Publishing. 60 p. [in Russian]

Martin D., Britayev T.A. 1998. Symbiotic polychaetes: review of known species // Oceanography and Marine Biology: an Annual Review. Vol.36. P.217-340.

Otto R.S., Macintosh R.A., Cummiskey P.A. 1990. Fecundity and other reproductive parameters of female the red king crab (Paralithodes camtschaticus) in Bristol Bay and Norton Sound, Alaska // Proceedings of the international symposium on king and tanner crabs. Univ. Alaska sea grant report. P.65-90.

Pavlova L.V. 2007. [Experimental studies on feeding of juveniles of the red king crab (Paralithodes camtschaticus) in the Barents Sea] // Zoologicheskij zhurnal. Vol.86. P.684-690 [in Russian].

Pereladov M.V. 2003. [Some peculiarities of distribution of the red king crab (Paralithodes camtschaticus) in offshore zone of Varanger Fjord (Barents Sea) in January-March, 2002] // Bottom ecosystems of the Barents Sea. Trudy VNIRO. Vol.142. P.103-119 [in Russian].

Shields J.D., A.M. Kuris. 1988. Temporal variation in abundance of the egg predator Carcinonemertes epialti (Nemertea) and its effect on egg mortality of its host, the shore crab, Hemigrapsus oregonensis // Hydrobilogia. Vol.156. P.31-38.

Shields J.D., Wickham D.E., Blau S.F. 1990. Some implications of egg mortality caused by symbiotic nemerteans for data acquisition and management strategies of red king crabs, Paralithodes camtschatica // Proceedings of the international symposium on king and tanner crabs. Univ. Alaska sea grant report. P.383395.

Steele D.H., Hooper R.G., Keats D. 1986. Two corophioid amphipods commensal on spider crabs in Newfoundland // Journal of Crustacean Biology. Vol.6. P.119124.

Uspenskaya A.V. 1963. [Fauna of parasites of benthic crustaceans of the Barents Sea]. Moscow-Leningrad: AN SSSR Publishing. 127 p. [in Russian]

Wickham, D.E., Blau S.F., Kuris A.M. 1985. Preliminary report on egg mortality in Alaskan king crab caused by the egg predator Carcinonemertes // Proceedings of the international king crab symposium. Univ. Alaska sea grant report. No 85-12. P.265-270.

Williams J.D., McDermott J.J. 2004. Hermit crab biocoenoses: a worldwide review of the diversity and natural history of hermit crab associates // Journal of experimental marine biology and ecology. Vol.305. P.1-128. 